\title{
Cholecystokinin receptors regulate sperm protein tyrosine phosphorylation via uptake of $\mathrm{HCO}_{3}^{-}$
}

\author{
Yuchuan Zhou ${ }^{1}$, Yanfei $\mathrm{Ru}^{1}$, Huijuan $\mathrm{Shi}^{2}$, Yanjiao Wang ${ }^{1,3}$, Bin $\mathrm{Wu}^{2}$, Halmurat Upur ${ }^{3}$ \\ and Yonglian Zhang ${ }^{1}$ \\ ${ }^{1}$ State Key Laboratory of Molecular Biology, Shanghai Key Laboratory for Molecular Andrology, Institute of \\ Biochemistry and Cell Biology, Shanghai Institutes for Biological Sciences, Chinese Academy of Sciences, \\ 320 Yueyang Road, Shanghai 200031, People's Republic of China, ${ }^{2}$ Shanghai institute of Planned Parenthood \\ Research, Shanghai, China and ${ }^{3}$ College of Basic Medical, Xinjiang Medical University, Urumqi, \\ Xinjiang Uygur Autonomous Region, Shanghai, China
}

Correspondence should be addressed to Y Zhang; Email: ylzhang@sibcb.ac.cn

\begin{abstract}
Cholecystokinin (CCK), a peptide hormone and a neurotransmitter, was detected in mature sperm two decades ago. However, the exact role of CCK and the types of CCK receptors (now termed CCK1 and CCK2) in sperm have not been identified. Here, we find that CCK1 and CCK2 receptors are immunolocalized to the acrosomal region of mature sperm. The antagonist of CCK1 or CCK2 receptor strongly activated the soluble adenylyl cyclase/cAMP/protein kinase A signaling pathway that drives sperm capacitation-associated protein tyrosine phosphorylation in dose- and time-dependent manners. But these actions of stimulation were abolished when sperm were incubated in the medium in the absence of $\mathrm{HCO}_{3}^{-}$. Further investigation demonstrated that the inhibitor of CCK1 or CCK2 receptor could accelerate the uptake of $\mathrm{HCO}_{3}^{-}$and significantly elevate the intracellular $\mathrm{pH}$ of sperm. Interestingly, the synthetic octapeptide of CCK (CCK8) showed the same action and mechanism as antagonists of CCK receptors. Moreover, CCK8 and the antagonist of CCK1 or CCK2 receptor were also able to accelerate human sperm capacitation-associated protein tyrosine phosphorylation by stimulating the influx of $\mathrm{HCO}_{3}^{-}$. Thus, the present results suggest that $\mathrm{CCK}$ and its receptors may regulate sperm capacitation-associated protein tyrosine phosphorylation by modulating the uptake of $\mathrm{HCO}_{3}^{-}$.

Reproduction (2015) 150 257-268
\end{abstract}

\section{Introduction}

During the process of mammalian fertilization, sperm must undergo a series of biochemical and physiological changes after maturation in the epididymis before they are able to fertilize eggs. This time-dependent acquisition of fertilizing competence has been defined as capacitation (Chang 1951, 1955, Austin 1952). Sperm capacitation normally occurs in the female genital tract. However, it has also been accomplished in vitro by using chemically defined media. In most cases, these media contain appropriate concentrations of electrolytes, metabolic energy sources and serum albumin (Visconti et al. 1998, Naz \& Rajesh 2004).

Capacitation involves an increase in membrane fluidity, cholesterol efflux, modifications in the distribution of surface protein; changes in enzymatic activities; modulation of intracellular constituents such as CAMP, $\mathrm{Ca}^{2+}$ and $\mathrm{HCO}_{3}^{-}$; and protein tyrosine phosphorylation (Brewis et al. 2005). In many mammalian species, protein tyrosine phosphorylation is considered an indicator of sperm capacitation and is associated with hyperactivated motility, zona pellucida binding and acrosome reaction (Visconti et al. 1995a,b, Visconti \& Kopf 1998, Zeng \& Tulsiani 2003, Baker et al. 2004). Now, it is widely accepted that sperm protein tyrosine phosphorylation is regulated by the soluble adenylyl cyclase (sAC)/cAMP/ protein kinase A (PKA) signaling pathway (Visconti et al. 2002). During capacitation, the entry of bicarbonate and calcium from the medium into the sperm cell activates SAC, resulting in elevated cAMP levels, subsequent PKA activation and protein tyrosine phosphorylation. However, little is known about hormonal control of this signaling pathway in sperm.

Cholecystokinin (CCK) is a small peptide hormone as well as an important neurotransmitter (Chandra \& Liddle 2007). It is widely and abundantly expressed in the central system and in digestive organs (Crawley \& Corwin 1994, Mutt 1994) and plays a critical role in digestion, feeding, cardiovascular function, respiratory function, neurotoxicity and seizures, cancer cell proliferation, analgesia, sleep, memory, anxiety and dopamine-mediated exploratory and rewarded behaviors (Crawley \& Corwin 1994). CCK has also been found in 
spermatogenic cells in the testis and epididymis (Persson et al. 1988, 1989, Pelto-Huikko et al. 1989) although its exact role remains elusive. CCK exerts physiologic functions through its specific membrane-spanning receptors. CCK receptors can be subdivided pharmacologically into type A and B receptors (now termed as CCK1 and CCK2 respectively according to the guidelines of the International Union of Pharmacology (IUPHAR) Committee on Receptor Nomenclature and Drug Classification) (Vanhoutte et al. 1996). The contribution of each receptor to CCK-stimulated action is varied. Some pharmacological studies using CCK receptor antagonists have indicated that the CCK2 is involved in anxiety, while CCK1 has been implicated in satiety and behavior (Hughes et al. 1990, Miyasaka et al. 1994, 2002, Wank 1995). The gene expression and/or protein distribution of CCK1 and CCK2 have been reported (Wank 1995, Bourassa et al. 1999). CCK1 is enriched in the pancreas and specific brain regions, whereas CCK2 is widely distributed throughout the CNS (Honda et al. 1993, Wank 1995, Matsusue et al. 1999). However, the expression of CCK receptors in mature sperm has not been reported. Interestingly, our previous studies have shown that tripeptidyl peptidase II (TPPII), a CCKinactivating serine peptidase (Rose et al. 1996), could regulate sperm function (Zhou et al. 2013). Thus, we speculated that CCK and its receptors might play the specific roles in sperm function. We undertook the present study to examine the roles of CCK and its receptors in mature sperm and to elucidate the underlying mechanisms.

\section{Materials and methods}

\section{Animals}

Mature C57 male mice (10-12 weeks) were purchased from the Animal Center of the Chinese Academy of Sciences (Shanghai, China). They were housed in the animal housing at our institute before manipulation. Food and water were freely available throughout the experiments. All protocols were conducted according to the approval of the Institute Animal Care Committee of Shanghai Institute of Biochemistry and Cell Biology (Permit Number: SYXK2007-0017).

\section{Detection of CCK and its receptor proteins on the sperm}

Western blot analysis of CCK and its receptor proteins in spermatozoa was conducted according to a previously described protocol (Zhou et al. 2008, 2013). Briefly, total protein extracts obtained from spermatozoa of cauda epididymis were resolved by electrophoresis on $12 \%$ SDS-polyacrylamide gels, transferred into PVDF $(0.45 \mu \mathrm{m})$ membranes and probed with rabbit polyclonal antibodies (anti-CCK8 antibody (Sigma: C2581): 1:5000; anti-CCK1 antibody (Sigma: SAB4503488): 1:5000; anti-CCK2 antibody (Abcam, Cambridge, UK: ab183124): 1:2000). The bound IgG was detected with goat anti-rabbit HRP (dilution: 1:10 000) (Calbiochem, Nottingham, UK) and developed using ECL Plus (Amersham). Protein was assayed by probing the blots with monoclonal antibodies against $\alpha$-tubulin (Sigma: T6074; 1:20 000).

\section{Indirect immunofluorescence}

Immunofluorescence was indirectly detected as described previously (Zhou et al. 2008, 2013). Sperm were washed out from the epididymal cauda and fixed in $4 \%$ paraformaldehyde for $30 \mathrm{~min}$ at room temperature, and the 1:100 diluted rabbit polyclonal antibodies to CCK8 (Sigma: C2581), CCK1 (Sigma: SAB4503488) and CCK2 (Abcam: ab183124) were applied. Then, FITC-labeled goat anti-rabbit IgG (Sigma: F9887) were used as the secondary antibodies (dilution: 1:200). All the images were taken using a BX51 fluorescence microscope (Olympus).

\section{Culture media and solvents}

Enriched Krebs-Ringer bicarbonate (EKRB) medium was used throughout the study for mouse sperm preparation and capacitation, and the preparation was adopted from previously published reports (Zeng \& Tulsiani 2003). The final composition of the medium was $120 \mathrm{mM} \mathrm{NaCl} ; 4.8 \mathrm{mM} \mathrm{KCl} ; 1.0 \mathrm{mM}$ $\mathrm{CaCl}_{2}, 1.2 \mathrm{mM} \mathrm{MgSO} 4,1.2 \mathrm{mM} \mathrm{KH_{2 }} \mathrm{PO}_{4}, 5 \mathrm{mM}$ glucose, $21 \mathrm{mM}$ sodium lactate, $0.25 \mathrm{mM}$ sodium pyruvate, $25 \mathrm{mM}$ $\mathrm{NaHCO}_{3}$ and $3 \mathrm{mg} / \mathrm{ml}$ BSA. All the chemicals were purchased from Sigma and were of the highest purity available. A tenfold concentrated solution of all the ingredients was first prepared without $\mathrm{CaCl}_{2}, \mathrm{BSA}$ and $\mathrm{NaHCO}_{3}$, sterilized by passage through a $0.22-\mu \mathrm{m}$ filter and stored at $-20{ }^{\circ} \mathrm{C}$ in single-use aliquots. Working media were prepared by adding $\mathrm{CaCl}_{2}$, $\mathrm{NaHCO}_{3}$ and BSA and gassing the medium with a mixture of $5 \% \mathrm{CO}_{2}$ and $95 \%$ air overnight at $\mathrm{pH} 7.2-7.4$. As described in a previous report (Visconti et al. 1995a), in some experiments, medium without $\mathrm{NaHCO}_{3}$ was derived by adding $25 \mathrm{mM} \mathrm{NaCl}$ instead of $25 \mathrm{mM} \mathrm{NaHCO}_{3}$. In some experiments, $\mathrm{Ca}^{2+}$ - and BSA-free media were used and the $\mathrm{Ca}^{2+}$ and BSA were added back to above final concentrations if necessary.

DMSO was used as solvent for CR1409 (Phoenix, CA, USA), PD135158 (Tocris, MO, USA), H89 (Sigma) and KH7 (Sigma). The maximal concentrations of CR1 409 and PD135158 stock solution are $100 \mathrm{mM}$ respectively according to the instructions. All the concentration of DMSO solvent is equal $0.1 \%$ among all samples in each experiment, except that the concentration of DMSO is $0.25 \%$ when CR1409 and PD135158 were used at the dose of $250 \mu \mathrm{M}$. We have found that the very low final concentration of nonaqueous solvents $(0.1,0.25$ and $0.5 \%$ DMSO) present in these experiments have no detectable effect on sperm function.

\section{Preparation of sperm}

The cauda epididymis was excised and freed from the fat pad, blood vessels and connective tissue. The tissue was then transferred to a dish containing $1 \mathrm{ml}$ EKRB medium prewarmed to $37^{\circ} \mathrm{C}$ and cut in several places with iridectomy scissors to release the spermatozoa into the medium. After $5 \mathrm{~min}$, the sperm suspension was transferred to a $5 \mathrm{ml}$ centrifuge tube. The final concentration of sperm was adjusted 
to $3-4 \times 10^{6}$ cells $/ \mathrm{ml}$ in appropriate medium. After incubation for various time periods and following treatment with different molecules or antagonists (CCK8 (Sigma: C2175); CR 1409 (Phoenix); PD135158 (Tocris), the sperm were concentrated by centrifugation at $6000 \mathrm{~g}$ for $2 \mathrm{~min}$ at room temperature, washed in PBS three times, resuspended in Laemmli's sample buffer without mercaptoethanol and boiled for $5 \mathrm{~min}$. After centrifuging at $6000 \boldsymbol{g}$ for $2 \mathrm{~min}$, the supernatant was collected and 2-mercaptoethanol was added to attain a final concentration of $5 \%$. The sperm extract was either used immediately or stored at $-70^{\circ} \mathrm{C}$ until analysis.

\section{Western blot for tyrosine and PKA substrate phosphorylation}

SDS-PAGE was carried out in $12 \%$ gel. The sperm extracts were electrophoretically transferred to PVDF membranes $(0.45 \mu \mathrm{m})$ in all experiments. The blots were blocked with blocking buffer (150 mM NaCl, $5 \mathrm{mM}$ EDTA, $50 \mathrm{mM}$ Tris- $\mathrm{HCl}, 0.05 \%$ (v/v) Triton X-100, $0.25 \%(\mathrm{~m} / \mathrm{v})$ gelatin; $\mathrm{pH} 7.5)$ and probed with a monoclonal antibody against phosphotyrosine (clone 4G10, Millipore) or the anti-phospho-PKA substrate (anti-pPKAs; 1:5000; clone 100G7E, Cell Signaling). The reactive bands were detected by enhanced chemiluminescence (Amersham, Buckinghamshire, UK). To confirm equal protein loading, the blots were stripped and reprobed with anti- $\alpha$-tubulin monoclonal antibody (Sigma: T6074; 1:20 000).

\section{Immunofluorescence staining for PKA substrate phosphorylation}

Sperm from epididymal cauda were collected and adjusted to 3-4× $10^{6}$ cells $/ \mathrm{ml}$ in EKRB medium. After treatment with CR 1409 (Phoenix) and PD135158 (Tocris) for five min, they were washed with PBS and fixed in 4\% paraformaldehyde for $30 \mathrm{~min}$ at room temperature. The 1:50 diluted rabbit anti-phospho-PKA substrate (anti-pPKAs; clone 100G7E, Cell Signaling) were applied. Then, FITC-labeled goat anti-rabbit IgG (Sigma: F9887) were used as the secondary antibodies (dilution: 1:200). All the images were taken using a BX51 fluorescence microscope (Olympus, Tokyo, Japan).

\section{Measurement of intracellular $\mathrm{pH}$ in sperm}

Sperm were collected and loaded with 1.2 $\mu \mathrm{M}$ BCECF-AM for 15 min in the medium $\left(37^{\circ} \mathrm{C}\right.$, under $\left.5 \% \mathrm{CO}_{2}\right)$. Afterward, the cells were pelleted and washed twice to remove free dye and adjusted to $1 \times 10^{7}$ cells per $\mathrm{ml}$ in incubation medium. When needed, CCK8 or CCK receptor antagonists were added and incubated for further appropriate time. The $\mathrm{pH}$ was determined as previously described (Fraire-Zamora \& Gonzalez-Martinez 2004). Fluorescence was detected by an excitation ratio of $500: 439 \mathrm{~nm}$ (emission, $550 \mathrm{~nm}$ ) using a luminescence spectrometer (BioTek, VT, USA). Calibration was performed according to the previous method (Fraire-Zamora \& Gonzalez-Martinez 2004).

\section{Assays on human sperm}

Human sperm capacitation medium (Biggers, Whitten and Whittingham (BWW)) had the following composition in $\mathrm{mM}$ :
94.8 $\mathrm{NaCl}, 4.8 \mathrm{KCl}, 1.7 \mathrm{CaCl}_{2}, 1.2 \mathrm{KH}_{2} \mathrm{PO}_{4}, 1.2 \mathrm{MgSO}_{4}, 0.27$ Na-pyruvate, $13.21 \mathrm{Na}$-lactate, 5.5 glucose and $25 \mathrm{NaHCO}_{3}$, with $3.5 \mathrm{mg} / \mathrm{ml} \mathrm{BSA} \mathrm{(fraction} \mathrm{V;} \mathrm{Sigma,} \mathrm{MO,} \mathrm{USA).} \mathrm{These}$ experiments using human sperm were approved by an institutional human research committee, and informed consent was obtained from the participants. Human ejaculates were obtained by masturbation, and processing began within $1 \mathrm{~h}$. The ejaculates had normal volume, sperm concentration and sperm motility according to World Health Organization criteria. Once washed by BWW solution, sperm were resuspended in the BWW medium and adjusted to $1 \times 10^{7}$ cells $/ \mathrm{ml}$ in incubation medium. Samples were used for western blot analysis of tyrosine phosphorylation and $\mathrm{pH}$ determination as described above after they were treated by CCK8 (Sigma: C2175) or CCK receptor antagonists (CR 1409 (Phoenix); PD135158 (Tocris).

\section{Results}

\section{CCK and its receptors locate on the acrosome region of mature sperm}

The indirect immunofluorescence assay indicated that the positive CCK signal was mainly located in the acrosome region of mouse sperm (Fig. 1A), consistent with the previous observation (Pelto-Huikko et al. 1989). However, a weak signal was also found on the principal piece of mouse sperm (Fig. 1A). This may be a nonspecific signal because of several unexpected bands in the western blotting analysis by using CCK antibody (Fig. 1B). Western blot analysis and immunofluorescence assay all validated that the CCK1 receptor and CCK2 receptor were specifically located on the region of sperm acrosome (Fig. 1C, D, E and F). The negative control with the omission of the first antibody showed no immunoreactive signals and bands in the immunofluorescence assay and western blot analysis (Fig. 1G and $\mathrm{H}$ ). It was observed that the size of the band for CCK1 receptor or CCK2 receptor $(\approx 72 \mathrm{kDa})$ was larger than that of the deduced size $(\approx 50 \mathrm{kDa})$.

\section{CCK receptor antagonists can accelerate sperm capacitation-associated protein tyrosine phosphorylation}

Since the function of CCK is mediated by its receptors, we considered that CCK1 and CCK2 receptors might play an important role in sperm function. Thus, we used CCK1 and CCK2 antagonists to test their effect on mature sperm function. We found that CCK1 or CCK2 receptor antagonist could accelerate protein tyrosine phosphorylation in a dose- and time-dependent manner (Fig. 2A and $\mathrm{B})$. The tyrosine phosphorylation reached the highest levels when the sperm were incubated for $60 \mathrm{~min}$ with $100 \mu \mathrm{M}$ CCK1 and $50 \mu \mathrm{M}$ CCK2 receptor antagonists. Unless otherwise noted, we used these two concentrations of the two antagonists and the incubation time of $60 \mathrm{~min}$ for the subsequent experiments in this study. These data suggested that CCK1 or CCK2 receptor 


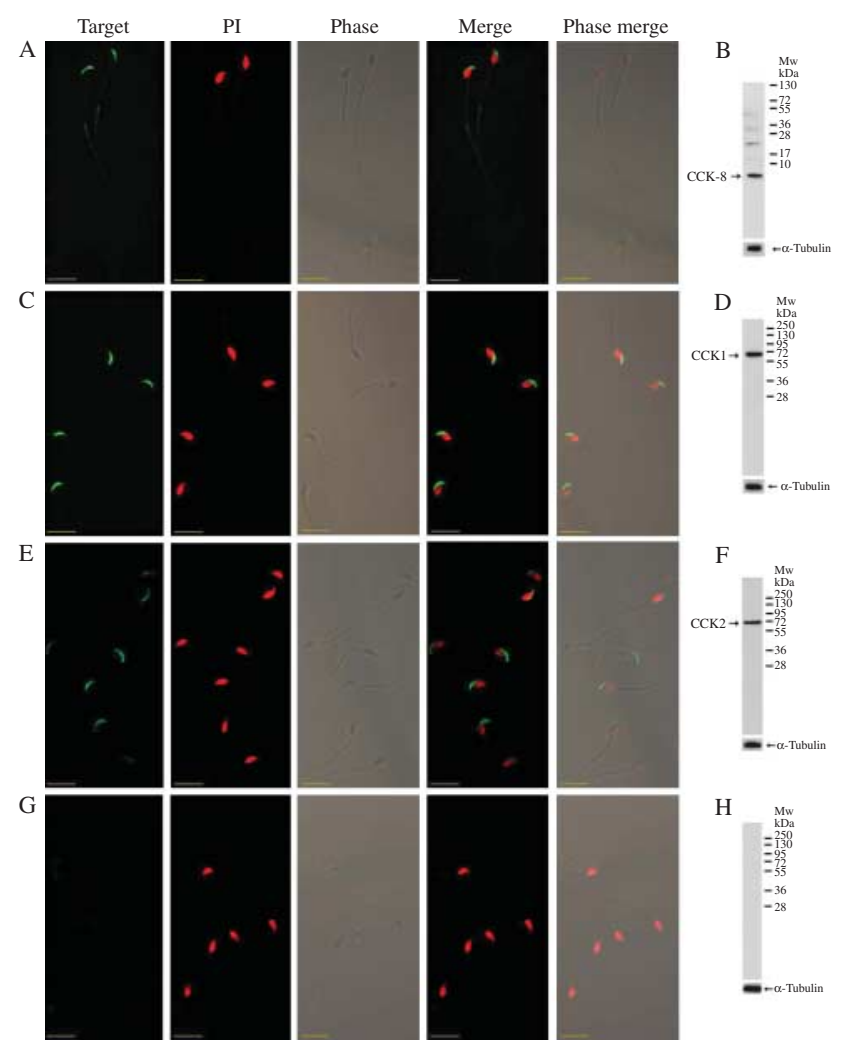

Figure 1 Characteristics of CCK and its receptor proteins in mouse sperm. (A, C, E and G) Immunofluorescence staining of CCK (A), CCK1 receptor $(\mathrm{C})$ and $\mathrm{CCK} 2$ receptor $(\mathrm{E})$ proteins on spermatozoa. Mouse cauda sperm were collected and probed with anti-CCK-8, CCK1 and CCK2 polyclonal antibodies. Control sperm were incubated only with (FITC)-labeled goat anti-rabbit IgG (G). Sperm DNA was stained with propidium iodide (PI) and can be seen in red. Bars: $10 \mu \mathrm{m}$. A representative of three independent experiments is shown. (B, D, $\mathrm{F}$ and $\mathrm{H}$ ) western blot analysis of CCK (B), CCK1 receptor (D) and CCK2 receptor $(\mathrm{F})$ proteins in cauda epididymal sperm of mouse. The negative control $(\mathrm{H})$ was conducted only by using goat anti-rabbit antibody conjugated with iaolian HRP. The blots were probed with monoclonal antibodies against $\boldsymbol{\alpha}$-tubulin to assess protein loading. The western blot is a representative of three independent experiments.

antagonist could significantly accelerate the sperm capacitation-associated tyrosine phosphorylation.

\section{CCK receptor antagonists can accelerate PKA substrate phosphorylation}

The serine/threonine phosphorylation of PKA substrate proteins is a critical event on the upstream of sperm capacitation-associated protein tyrosine phosphorylation (Battistone et al. 2013). To examine whether CCK receptor antagonists have the influence on PKA substrate phosphorylation, we determined the change of PKA substrate phosphorylation in sperm treated with CCK receptor antagonists. The western blot analysis demonstrated that CCK1 or CCK2 receptor antagonist could increase PKA substrate phosphorylation (Fig. 3A). The indirect immunofluorescence staining further showed that the signals of PKA substrate phosphorylation were enhanced by CCK1 or CCK2 receptor antagonist (Fig. 3B). These data indicated that CCK1 or CCK2 receptor antagonist could significantly promote PKA substrate phosphorylation.

\section{Activation of sperm sAC/cAMP/PKA pathway by $C C K$ receptor antagonists depends on the extracellular $\mathrm{HCO}_{3}^{-}$}

It is widely accepted that sperm capacitation-associated protein tyrosine phosphorylation is regulated by the sAC/cAMP/ PKA pathway. The presence of BSA, $\mathrm{Ca}^{2+}$
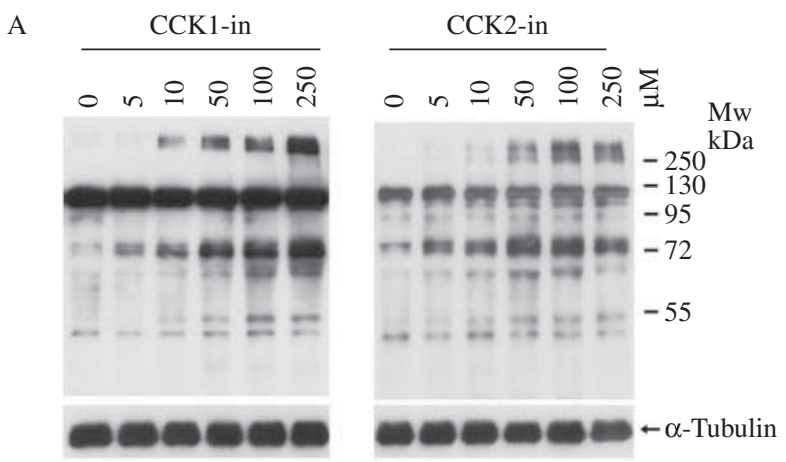

B

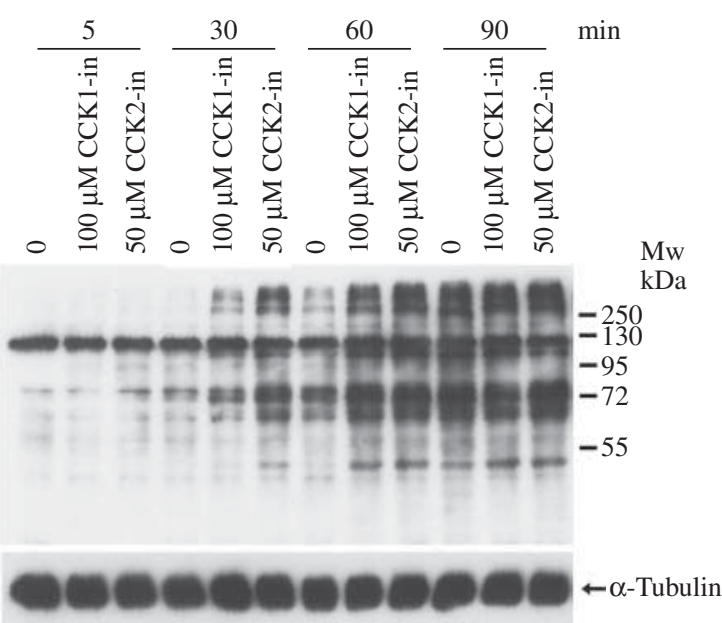

Figure 2 Effects of CCK receptor antagonists on sperm capacitationassociated protein tyrosine phosphorylation. (A) Dose-dependent effects of CCK receptor antagonists on sperm protein tyrosine phosphorylation. Sperm were incubated with CCK receptor antagonists CR 1409 (CCK1-in: 0, 5, 10, 50, 100 and $250 \mu \mathrm{M}$ ) and PD135158 (CCK2-in: 0, 5 10, 50, 100 and $250 \mu \mathrm{M}$ ) for $1 \mathrm{~h}$. Protein tyrosine phosphorylation was assessed by western blot analysis. $\alpha$-Tubulin was used as the loading control. The western blot is a representative of five independent experiments. (B) Time-dependent effects of CCK receptor antagonists on sperm protein tyrosine phosphorylation. Spermatozoa were incubated with CCK receptor antagonists CR 1409 (CCK1-in, $100 \mu \mathrm{M})$ and PD135158 (CCK2-in, $50 \mu \mathrm{M})$ for 5, 30, 60 and $90 \mathrm{~min}$. Protein tyrosine phosphorylation was assessed by western blot analysis. $\alpha$-Tubulin was used as the loading control. The western blot is a representative of five independent experiments. 
A

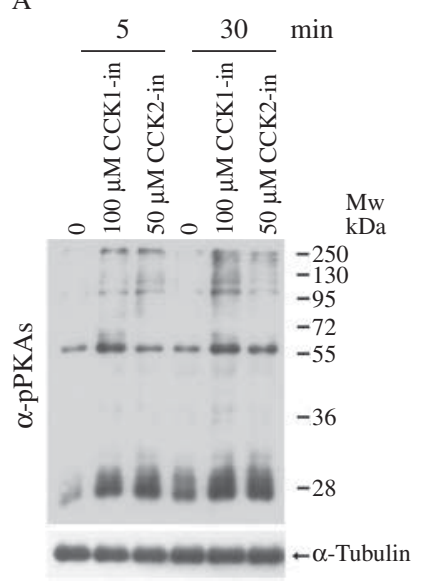

B
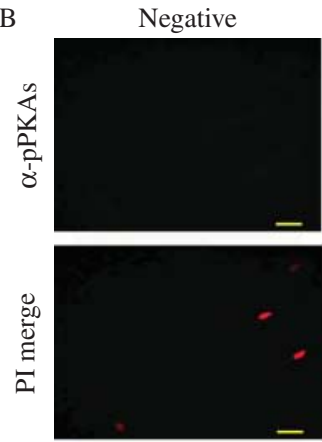

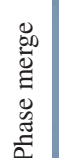

0
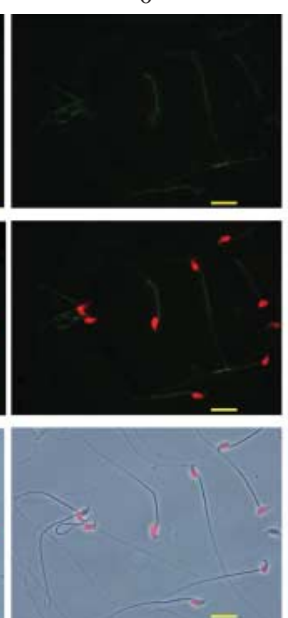

$100 \mu \mathrm{M}$ CCK1-in
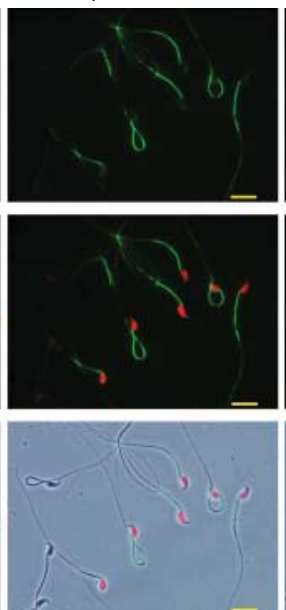

$50 \mu \mathrm{M}$ CCK2-in
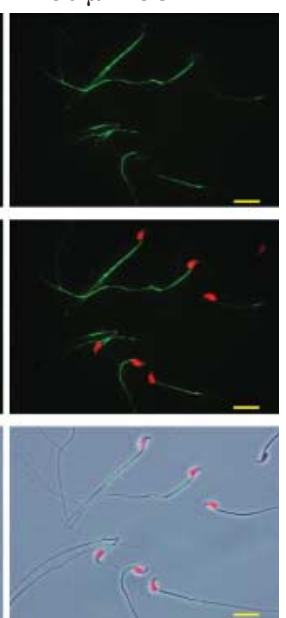

Figure 3 Effects of CCK receptor antagonists on sperm PKA substrate phosphorylation. (A) Spermatozoa were treated with the CCK receptor antagonists CR 1409 (CCK1-in, $100 \mu \mathrm{M}$ ) and PD135158 (CCK2-in, $50 \mu \mathrm{M})$ for 5 and 30 min respectively. PKA substrate phosphorylation ( $\alpha$-pPKAs) was then assessed by western blot analysis. $\alpha$-Tubulin was used as the loading control. The western blot is a representative of three independent experiments. (B) Spermatozoa were treated with the CCK receptor antagonists CR 1409 (CCK1-in, $100 \mu M$ ) and PD135158 (CCK2-in, $50 \mu$ M) for 5 min. PKA substrate phosphorylation ( $\alpha$-pPKAs) was then assessed by indirect immunofluorescence analysis. Control sperm were incubated only with (FITC)-labeled goat anti-rabbit IgG (negative). Sperm DNA was stained with propidium iodide (PI) and can be seen in red. Bars: $10 \mu \mathrm{m}$.

A representative of three independent experiments is shown.

and $\mathrm{HCO}_{3}^{-}$in the medium is essential for the activation of this pathway (Visconti et al. 1995a). To test whether the effects of CCK receptor antagonists on tyrosine phosphorylation are related to the sAC/CAMP/PKA pathway, we used a highly selective blocker (H89) of PKA and a specific inhibitor (KH7) of sAC. The results showed that $\mathrm{H} 89$ and $\mathrm{KH} 7$ all suppressed the increase of protein tyrosine phosphorylation stimulated by CCK receptor antagonists (Fig. 4A and B). These findings suggested that the CCK receptor antagonist-induced activation of tyrosine phosphorylation was located upstream of PKA and SAC action. Furthermore, we examined the effect of CCK receptor antagonists on tyrosine phosphorylation of sperm incubated in media devoid of $\mathrm{BSA}, \mathrm{HCO}_{3}^{-}$and $\mathrm{Ca}^{2+}$. When the sperm were incubated in the absence of BSA or $\mathrm{HCO}_{3}^{-}$for $1 \mathrm{~h}$, the acceleration of tyrosine phosphorylation induced by CCK receptor antagonists disappeared (Fig. 5A and B). This demonstrated that the effect of CCK receptor antagonists on tyrosine phosphorylation was dependent on the presence of BSA and $\mathrm{HCO}_{3}^{-}$in the medium. As illustrated in Fig. 5C, CCK receptor antagonists could accelerate tyrosine phosphorylation in the absence of extracellular $\mathrm{Ca}^{2+}$. To chelate the traces of $\mathrm{Ca}^{2+}$ in $\mathrm{Ca}^{2+}$-free medium, EGTA at a final concentration of $25 \mu \mathrm{M}$ was used. But this treatment could not abolish CCK receptor antagonist-induced change of sperm tyrosine phosphorylation (Fig. 5C). Moreover, BAPATAM $(25 \mu \mathrm{M})$, an intracellular $\mathrm{Ca}^{2+}$ chelator, could not still block the CCK receptor antagonist-induced increase of sperm tyrosine phosphorylation (Fig. 5C). These results revealed that the acceleration of tyrosine phosphorylation by CCK receptor antagonists was independent on extracellular or intracellular $\mathrm{Ca}^{2+}$ of sperm.

\section{CCK receptor antagonists can elevate intracellular $\mathrm{pH}$ by uptake of $\mathrm{HCO}_{3}^{-}$}

The presence of extracellular free $\mathrm{HCO}_{3}^{-}$in the medium is essential for sperm protein tyrosine phosphorylation. Media lacking $\mathrm{HCO}_{3}^{-}$and buffered to various $\mathrm{pHs}(\mathrm{pH}$ 5-9) and alkalinization of intracellular $\mathrm{pH}$ with $\mathrm{NH}_{4} \mathrm{Cl}$ all did not mimic this $\mathrm{HCO}_{3}^{-}$effect on protein tyrosine phosphorylation (Schackmann \& Chock 1986, Visconti et al. 1995a). Our above observation indicated that CCK receptor antagonists accelerated protein tyrosine phosphorylation only when sperm were incubated in a presence of $\mathrm{HCO}_{3}^{-}$medium. We also found that the antagonist of CCK1 or CCK2 receptor have no influence on $\mathrm{pH}$ of medium (data not shown). We hypothesized that intracellular $\mathrm{HCO}_{3}^{-}$in sperm might be elevated by receptor antagonists. To test this hypothesis, we investigated the effect of receptor antagonists on intracellular $\mathrm{HCO}_{3}^{-}$in sperm by examining the change of intracellular $\mathrm{pH}$ according to the previous report ( $\mathrm{Xu}$ et al. 2007). The two antagonists were respectively added to the sperm suspension and incubated for $1 \mathrm{~h}$. The result showed that both antagonists significantly increased the sperm intracellular $\mathrm{pH}$ in the dose-dependent manners (Fig. 6A). Moreover, as shown in Fig. 6B, the antagonistinduced increase in $\mathrm{pH}$ level was fast. The free cytosolic $\mathrm{pH}$ in the sperm was continuously elevated since the CCK receptor antagonists were added into the 

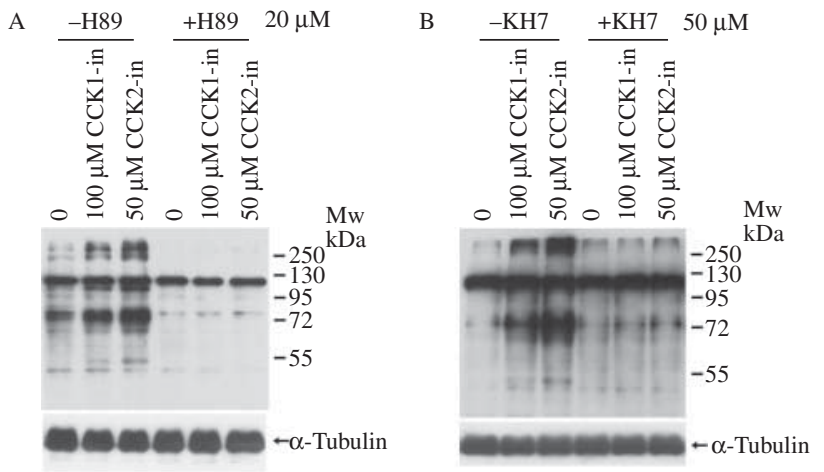

Figure 4 Activation of sperm sAC/cAMP/PKA pathway by CCK receptor antagonists. (A) Spermatozoa were treated with the CCK receptor antagonists CR 1409 (CCK1-in, $100 \mu \mathrm{M})$ and PD135158 (CCK2-in, $50 \mu \mathrm{M})$ for $60 \mathrm{~min}$ in the absence or presence of $20 \mu \mathrm{M}$ the protein kinase A (PKA) inhibitor H89. Protein tyrosine phosphorylation was then assessed by western blot analysis. $\alpha$-Tubulin was used as the loading control. The western blot is a representative of three independent experiments. (B) Spermatozoa were treated with the CCK receptor antagonists CR 1409 (CCK1-in, $100 \mu \mathrm{M}$ ) and PD135158 (CCK2-in, $50 \mu \mathrm{M}$ ) for $60 \mathrm{~min}$ in the absence or presence of $50 \mu \mathrm{M} \mathrm{KH} 7$. Protein tyrosine phosphorylation was then assessed by western blot analysis. $\alpha$-Tubulin was used as the loading control. The western blot is a representative of three independent experiments.

$\mathrm{HCO}_{3}^{-}$Containing medium. These data suggested that CCK receptor antagonists can stimulate uptake of $\mathrm{HCO}_{3}^{-}$in sperm.

\section{CCK8 can activate $s A C / c A M P / P K A$ pathway by inducing the influx of $\mathrm{HCO}_{3}^{-}$}

Since CCK is the ligand of CCK 1 and CCK2 receptors, we investigated its action by using chemically synthetic polypeptide CCK8. We found that CCK8 could accelerate protein tyrosine phosphorylation in the dose-dependent manner (Fig. 7A) and promote the PKA substrate phosphorylation (Fig. 7B). The increase of protein tyrosine phosphorylation was abolished by the blocker (H89) of PKA and the inhibitor $(\mathrm{KH} 7)$ of SAC (Fig. 7C and D). Moreover, the CCK8-stimulating acceleration of tyrosine phosphorylation was dependent on the presence of BSA and $\mathrm{HCO}_{3}^{-}$, but not $\mathrm{Ca}^{2+}$ in the medium (Fig. 7E, F and G). Further investigation indicated that CCK8 could trigger the rapid increase of $\mathrm{pH}$ in the sperm (Fig. $7 \mathrm{H}$ ). These results suggested that CCK8 can regulate the activation of sAC/CAMP/ PKA pathway by inducing the influx of $\mathrm{HCO}_{3}^{-}$in the sperm.

\section{CCK8 exerts its action by inhibiting CCK1 and CCK2 receptors}

Generally, the inhibitors have the biphasic doseresponse. Although CCK8 showed the same action on sperm function as the inhibitors of CCK receptors, the activation or inhibition of CCK1 and CCK2 receptors by
CCK8 and their inhibitors needs to be addressed. To answer this question, we further investigated the effects of antibodies against CCK1 and CCK2 receptors on sperm function. The results indicated that the antibody against CCK1 or CCK2 receptor could accelerate the sperm protein tyrosine phosphorylation (Fig. 8A) and elevate the level of intracellular pHin sperm (Fig. 8B). Moreover, the high (100 $\mu \mathrm{M}$ CCK1-in; $50 \mu \mathrm{M}$ CCK2-in) and low $(0.25 \mu \mathrm{M}$ CCK1-in and CCK2-in) doses of inhibitors, as well as the antibodies against CCK receptors showed similar superposition effect on sperm with CCK8 (Fig. 8). These data demonstrated that CCK8
A

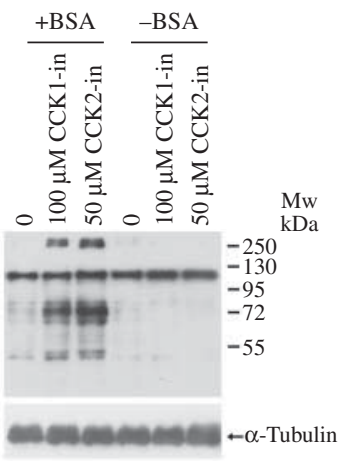

C

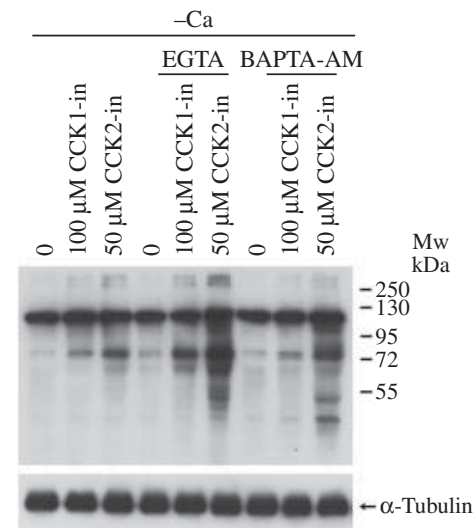

B

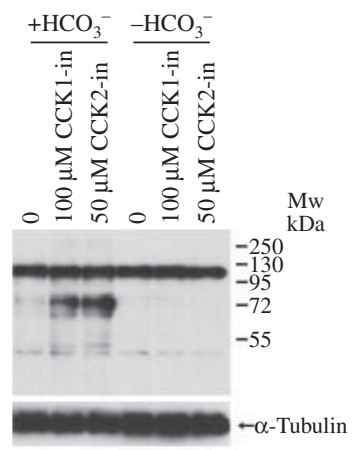

Figure 5 Activation of sperm tyrosine phosphorylation by CCK receptor antagonists depends on the extracellular BSA and $\mathrm{HCO}_{3}^{-}$. (A) Sperm were treated with the CCK receptor antagonists CR 1409 (CCK1-in, $100 \mu \mathrm{M}$ ) and PD135158 (CCK2-in, $50 \mu \mathrm{M}$ ) for $60 \mathrm{~min}$ in the absence or presence of $3 \mathrm{mg} / \mathrm{ml}$ BSA. Protein tyrosine phosphorylation was then assessed by western blot analysis. $\boldsymbol{\alpha}$-Tubulin was used as the loading control. The western blot is a representative of three independent experiments. (B) Sperm were treated with the CCK receptor antagonists CR 1409 (CCK1-in, $100 \mu \mathrm{M})$ and PD135158 (CCK2-in, $50 \mu \mathrm{M})$ for $60 \mathrm{~min}$ in the absence or presence of $25 \mathrm{mM} \mathrm{HCO}_{3}^{-}$. Protein tyrosine phosphorylation was then assessed by western blot analysis. $\alpha$-Tubulin was used as the loading control. The western blot is a representative of three independent experiments. (C) In the $\mathrm{Ca}^{2+}$-free medium, Sperm were treated with the CCK receptor antagonists CR 1409 (CCK1-in, $100 \mu \mathrm{M})$ and PD135158 (CCK2-in, $50 \mu \mathrm{M})$ for $60 \mathrm{~min}$ in the absence or presence of EGTA $(25 \mu \mathrm{M})$ or BAPTA-AM $(25 \mu \mathrm{M})$. Protein tyrosine phosphorylation was assessed by western blot analysis. $\alpha$-Tubulin was used as the loading control. The western blot is a representative of three independent experiments. 

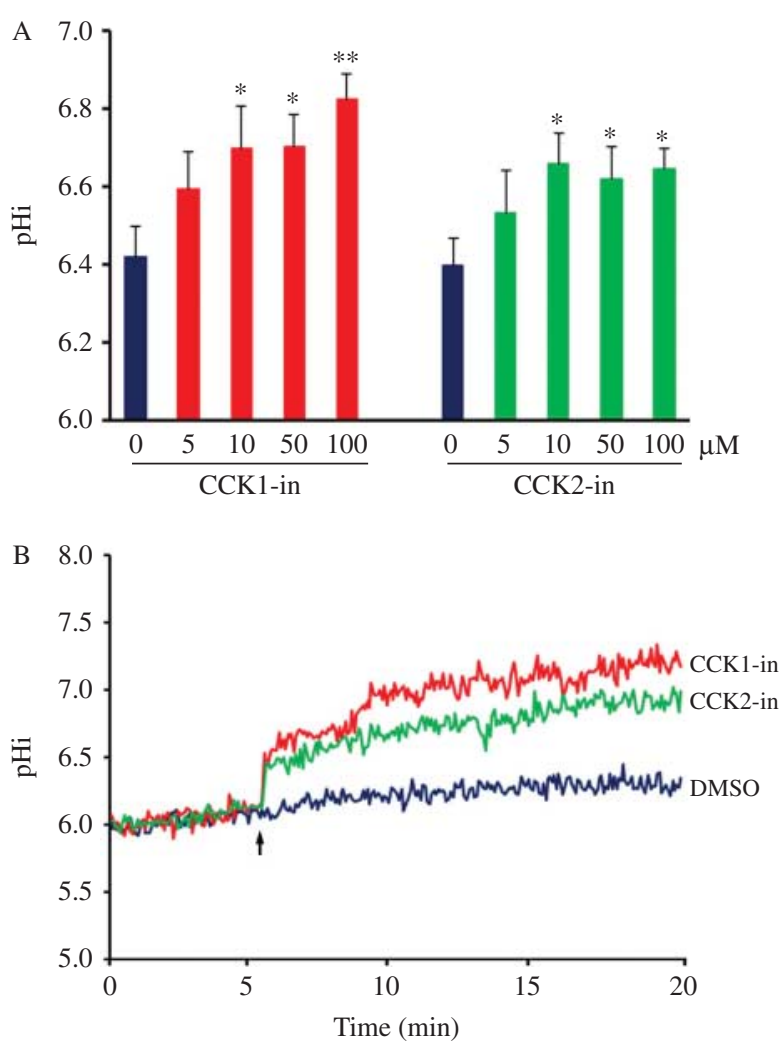

Figure 6 CCK receptor antagonists stimulate sperm tyrosine phosphorylation by increasing intracellular $\mathrm{pH}$ via the influx of $\mathrm{HCO}_{3}^{-}$. (A) Spermatozoa were treated with the CCK receptor antagonists $\mathrm{CR}$ 1409 (CCK1-in, 0, 5, 10, 50 and $100 \mu \mathrm{M}$ ) and PD135158 (CCK2-in, 0, $5,10,50$ and $100 \mu \mathrm{M}$ ) for $60 \mathrm{~min}$, and then the intracellular $\mathrm{pH}$ $(\mathrm{pHi})$ level in the sperm was examined. Results are expressed as the means \pm S.E.M. $(n=5) .{ }^{*} P<0.05,{ }^{*} P<0.01$, as compared with the corresponding controls (0) (unpaired $t$-test). (B) Effects of CCK receptor antagonists CR 1409 (CCK1-in, $100 \mu \mathrm{M})$ and PD135158 (CCK2-in, $50 \mu \mathrm{M})$ on sperm intracellular $\mathrm{pH}(\mathrm{pHi})$. The arrow indicates the time points at which the antagonists were added. A representative of four experiments is presented. Control (DMSO) is the basal level.

and CCK receptor antagonists increased protein tyrosine phosphorylation and influx of $\mathrm{HCO}_{3}^{-}$by inhibiting CCK1 and CCK2 receptors.

\section{CCK8 and CCK receptor antagonists can activate sAC/cAMP/ PKA pathway by inducing the influx of $\mathrm{HCO}_{3}^{-}$in human sperm}

To investigate whether CCK8 and its receptor antagonists play functional roles in human sperm, we treated human sperm with CCK8 and CCK receptor antagonists and then determined the levels of protein tyrosine and PKA substrate phosphorylation and $\mathrm{pH}$ in human sperm. The results demonstrated that CCK8 and CCK1 or CCK2 receptor antagonist could stimulate the acceleration of protein tyrosine and PKA substrate phosphorylation (Fig. 9A and B) and the increase of intracellular $\mathrm{pH}$ in human sperm (Fig. 9C). These data suggested that
CCK8 and CCK receptor antagonists could activate sAC/CAMP/PKA pathway by inducing the influx of $\mathrm{HCO}_{3}^{-}$in human sperm.

\section{Discussion}

This study provides the first characterization of CCK1 and CCK2 receptors and their role in the mature sperm of mice and humans. Based on the localization of CCK in the spermatogenic cells, together with the presence of CCK receptors on oocytes, previous researchers raised the possibility that CCK may be of importance in the fertilization process by its release from sperm and then action on the oocyte (Moriarty et al. 1988, Persson et al. 1988, Pelto-Huikko et al. 1989). Our present results show that CCK and its receptors all locate on the acrosome region of mature sperm, and they are involved in the regulation of sperm capacitation-associated tyrosine phosphorylation. These results suggest that CCK and its receptors can regulate specific functions in mature sperm.

CCK1 and CCK2 receptors are all heavily glycosylated. Up to now, scarcely any reports showed that the native size of CCK1 or CCK2 receptor is identical to the predicted size. The deduced sequence of the rat CCK1 receptor corresponds to a 429-amino-acid protein with a calculated molecular mass of $48 \mathrm{kDa}$, but the purified CCK1 receptor from rat pancreas have a molecular mass of $85-95 \mathrm{kDa}$ (Wank et al. 1992). The rat and canine CCK2 receptors are 452 and 453 amino acids long respectively, but their molecular masses are identified to be 74-78 kDa (Svoboda et al. 1982, Noble et al. 1999). The molecular mass of CCK2 receptor in human tissue is approximate $80 \mathrm{kDa}$ (Kulaksiz et al. 2000). By sequence analysis at http://www.uniprot.org/uniprot/O08786 for CCK1 receptor and http://www.uniprot.org/uniprot/ P56481 for CCK2 receptor. We found that mouse CCK receptor sequence contained three sites (CCK1 receptor at position 10, 24 and 190; and CCK2 receptor at position 7, 30 and 36) for $\mathrm{N}$-linked glycosylation. These sites are the same as the glycosylation sites of other species CCK receptor, so it is reasonable that the molecular mass of mouse CCK1 or CCK2 receptor was all larger than that of the deduced size.

The specificity and toxicity should be considered with great caution when some inhibitors are used to evaluate the function of proteins or channels. Sperm are specialized cells and have a highly condensed nucleus. Generally, somatic cells are more sensitive than sperm to the same stimulation, so the different concentrations of inhibitors are required to modulate somatic cell and sperm functions. The $\mathrm{IC}_{50}$ values of $\mathrm{H} 89$ (PKA inhibitor) is $80 \mathrm{nM}$, but its working concentration for mouse sperm was 10-100 $\mu \mathrm{M}$ (Visconti et al. 1995b). Even for sperm, the dosage of a certain inhibitor is deferent between the species. The $\mathrm{IC}_{50}$ of the SFK (Src family kinase) inhibitor SK1606 in human sperm was five times lower than the 
one observed in mouse sperm (Krapf et al. 2010, Battistone et al. 2013). Our present results showed that $5 \mu \mathrm{M}$ CCK1 or CCK2 receptor antagonist could stimulate the increase of tyrosine phosphorylation (Fig. 2A). We further found that $0.1 \mu \mathrm{M}$ CCK1 or CCK2 receptor antagonist could also moderately exert these actions (Supplementary Figure 1, see section on supplementary data given at the end of this article). However, CCK1 or CCK2 receptor antagonist at the dosage of $5 \mu \mathrm{M}$ could moderately but not significantly increase the level of intracellular pH (Fig. 6A). Thus, we investigated the effects of CCK receptor antagonists on sperm functions at the relatively higher concentrations within the effectual doses.

The protein tyrosine phosphorylation is one of the most important events of sperm capacitation (Visconti \& Kopf 1998, Roberts et al. 2003, Zeng \& Tulsiani 2003, Baker et al. 2004). Our study indicated that the antagonists of CCK receptors and CCK8 could accelerate the capacitation-associated tyrosine phosphorylation

A

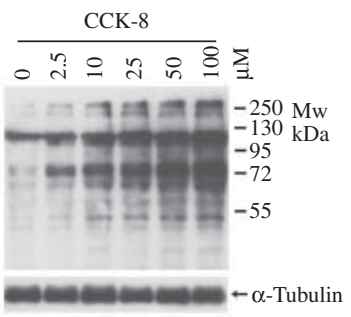

B $\quad \frac{5}{0} \quad 25 \quad \frac{30}{0} \quad 25 \mu$ min CCK-8

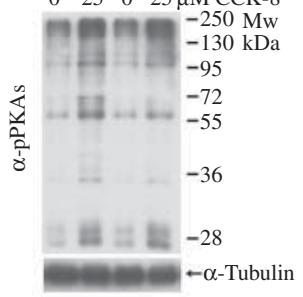

$\mathrm{C}$

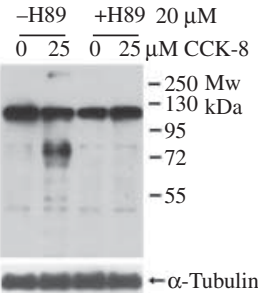

$\mathrm{F}$

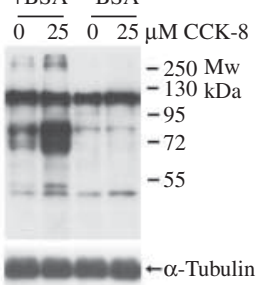

G

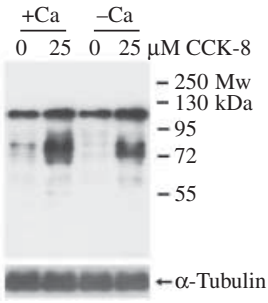

D $-\mathrm{KH} 7+\mathrm{KH} 750 \mu \mathrm{M}$

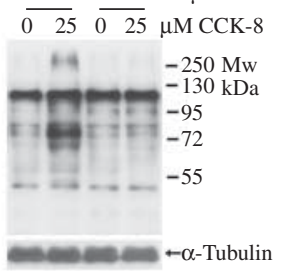

$\mathrm{F}+\mathrm{HCO}_{3}{ }^{-}-\mathrm{HCO}_{3}$
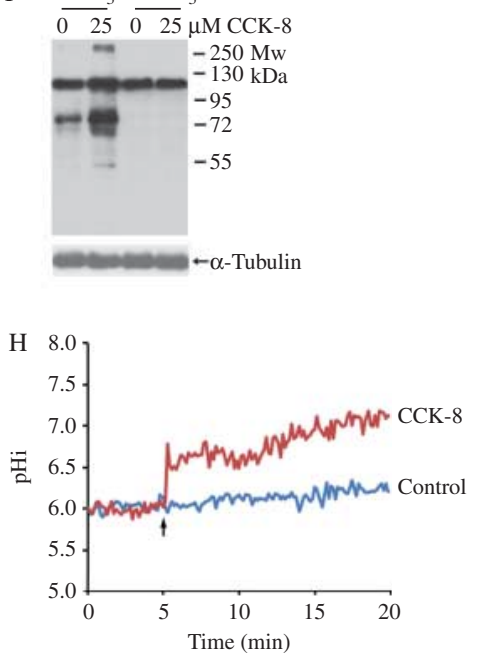

of sperm. Moreover, this regulation was found to be dependent on SAC and PKA, as well as extracellular BSA and $\mathrm{HCO}_{3}^{-}$, consistent with the activation of the sAC/cAMP/PKA pathway.

Both the CCK1 and CCK2 receptors belong to the family of seven transmembrane domain G-protein coupled receptors which activate the signal transduction cascade of phospholipase $\mathrm{C}$, with the formation of the second messengers, inositol 1,4,5-triphosphate (IP3) and 1,2-diacylglycerol, leading to the release of intracellular $\mathrm{Ca}^{2+}$ (Wank 1995, Dunlop 1998). More and more evidence indicated that CCK and native or recombinant CCK1 and CCK2 receptors were coupled to the mobilization of intracellular $\mathrm{Ca}^{2+}$ (Matozaki et al. 1988, 1990, Lee et al. 1993, Dunlop et al. 1996, 1997, Shimazoe et al. 2008). The antagonist of CCK1 or CCK2 receptor could significantly affect physiological functions of different cell types by modulating intracellular $\mathrm{Ca}^{2+}$ concentration (Muller et al. 1997, Dunlop et al. 1998, Simasko et al. 2002, Yang et al. 2007). $\mathrm{Ca}^{2+}$ is essential for the activation of the sAC/cAMP/PKA pathway in sperm. The time-dependent increase in sperm capacitation-associated tyrosine phosphorylation is

Figure 7 CCK8 can regulate sAC/cAMP/ PKA pathway by increasing intracellular $\mathrm{pH}$ via the influx of $\mathrm{HCO}_{3}{ }^{-}$. (A) Dose-dependent effect of CCK8 on sperm protein tyrosine phosphorylation. Sperm were incubated with CCK8 $(0,2.5,10,25,50$ and $100 \mu \mathrm{M})$ for $60 \mathrm{~min}$. Protein tyrosine phosphorylation was assessed by western blot analysis. $\alpha$-Tubulin was used as the loading control. The western blot is a representative of three independent experiments. (B) Spermatozoa were treated with the CCK8 $(25 \mu \mathrm{M})$ for 5 and 30 min respectively. PKA substrate phosphorylation ( $\alpha$-pPKAs) was then assessed by western blot analysis. $\boldsymbol{\alpha}$-Tubulin was used as the loading control. The western blot is a representative of three independent experiments. (C) Spermatozoa were treated with the CCK8 $(25 \mu \mathrm{M})$ for $60 \mathrm{~min}$ in the absence or presence of $20 \mu \mathrm{M}$ of the protein kinase A (PKA) inhibitor H89. Protein tyrosine phosphorylation was then assessed by western blot analysis. $\alpha$-Tubulin was used as the loading control. The western blot is a representative of three independent experiments. (D) Spermatozoa were treated with the CCK8 $(25 \mu \mathrm{M})$ for $60 \mathrm{~min}$ in the absence or presence of $50 \mu \mathrm{M} \mathrm{KH7}$. Protein tyrosine phosphorylation was then assessed by western blot analysis. $\alpha$-Tubulin was used as the loading control. The western blot is a representative of three independent experiments. (E) Sperm were treated with the CCK8 $(25 \mu \mathrm{M})$ for $60 \mathrm{~min}$ in the absence or presence of $3 \mathrm{mg} / \mathrm{ml}$ BSA. Protein tyrosine phosphorylation was then assessed by western blot analysis. $\alpha$-Tubulin was used as the loading control. The western blot is a representative of three independent experiments. (F) Sperm were treated with the CCK8 $(25 \mu \mathrm{M})$ for $60 \mathrm{~min}$ in the absence or presence of $25 \mathrm{mM} \mathrm{HCO}_{3}{ }^{-}$. Protein tyrosine phosphorylation was then assessed by western blot analysis. $\alpha$-Tubulin was used as the loading control. The western blot is a representative of three independent experiments. (G) Sperm were treated with the CCK8 $(25 \mu \mathrm{M})$ for $60 \mathrm{~min}$ in the absence or presence of $1 \mathrm{mM} \mathrm{Ca}^{2+}$. Protein tyrosine phosphorylation was assessed by western blot analysis. $\alpha$-Tubulin was used as the loading control. The western blot is a representative of three independent experiments. $(\mathrm{H})$ Effect of CCK8 $(25 \mu \mathrm{M})$ on sperm intracellular $\mathrm{pH}(\mathrm{pHi})$. The arrow indicates the time points at which the antagonists were added. A representative of four experiments is presented. 

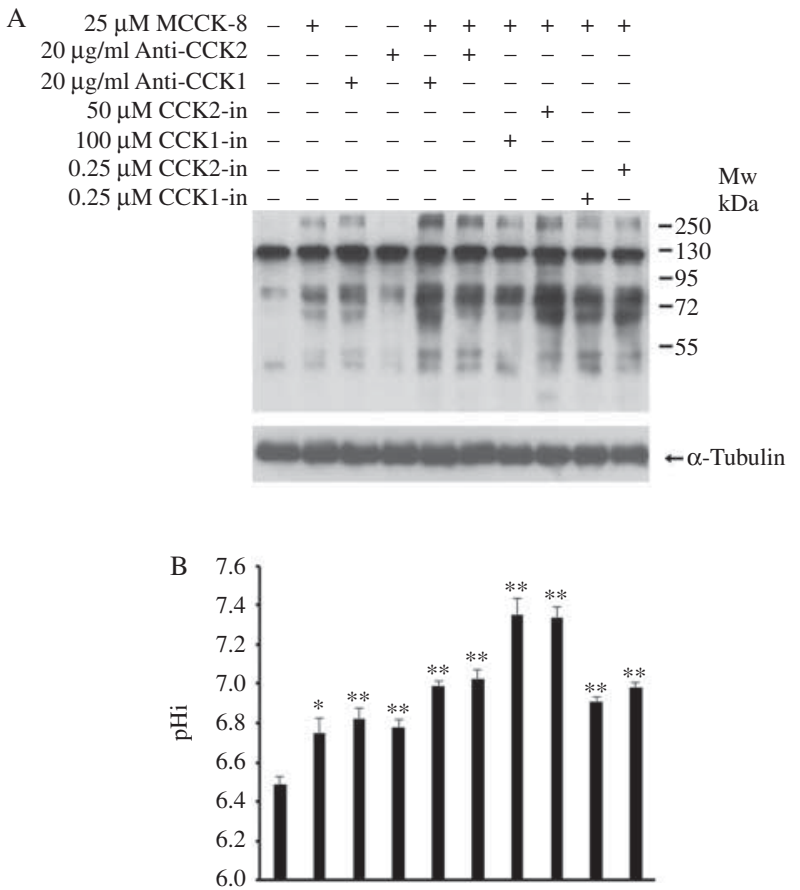

$25 \mu \mathrm{M}$ MCCK-8

$\begin{array}{rcccccccccc}25 \mu \mathrm{M} \text { MCCK-8 } & - & + & - & - & + & + & + & + & + & + \\ 20 \mu \mathrm{g} / \mathrm{ml} \text { Anti-CCK2 } & - & - & - & + & - & + & - & - & - & - \\ 20 \mu \mathrm{g} / \mathrm{ml} \text { Anti-CCK1 } & - & - & + & - & + & - & - & - & - & - \\ 50 \mu \mathrm{M} \text { CCK2} 2-i n & - & - & - & - & - & - & - & + & - & - \\ 100 \mu \mathrm{M} \text { CCK1-in } & - & - & - & - & - & - & + & - & - & - \\ 0.25 \mu \mathrm{M} \text { CCK2-in } & - & - & - & - & - & - & - & - & - & + \\ 0.25 \mu \mathrm{M} \text { CCK1-in } & - & - & - & - & - & - & - & - & + & -\end{array}$

Figure 8 CCK8 exerts its action by inhibiting CCK1 and CCK2 receptors. (A) The effects of CCK8, inhibitors and antibodies of CCK1 and CCK2 receptors on sperm protein tyrosine phosphorylation. Sperm were incubated with CCK8 $(25 \mu \mathrm{M})$, CCK1 antibody $(20 \mu \mathrm{g} / \mathrm{ml})$ or CCK2 antibody $(20 \mu \mathrm{g} / \mathrm{ml})$, and CCK1 antibody $(20 \mu \mathrm{g} / \mathrm{ml})$, CCK2 antibody $(20 \mu \mathrm{g} / \mathrm{ml})$, CR 1409 (CCK1-in, $100 \mu \mathrm{M})$, PD135158 (CCK2-in, $50 \mu \mathrm{M})$, CR 1409 (CCK1-in, $0.25 \mu \mathrm{M}$ ) and PD135158 (CCK2-in, $0.25 \mu \mathrm{M}$ ) in the presence of CCK8 $(25 \mu \mathrm{M})$ for $60 \mathrm{~min}$. Protein tyrosine phosphorylation was assessed by western blot analysis. $\alpha$-Tubulin was used as the loading control. The western blot is a representative of three independent experiments. (B) Sperm were incubated with CCK8 $(25 \mu \mathrm{M})$, CCK1 antibody $(20 \mu \mathrm{g} / \mathrm{ml})$ or CCK2 antibody $(20 \mu \mathrm{g} / \mathrm{ml})$, and CCK1 antibody $(20 \mu \mathrm{g} / \mathrm{ml})$, CCK2 antibody $(20 \mu \mathrm{g} / \mathrm{ml})$, CR 1409 (CCK1-in, $100 \mu \mathrm{M})$, PD135158 (CCK2-in, $50 \mu \mathrm{M}), \mathrm{CR} 1409$ (CCK1-in, $0.25 \mu \mathrm{M})$ and PD135158 (CCK2-in, $0.25 \mu \mathrm{M}$ ) in the presence of CCK8 $(25 \mu \mathrm{M})$ for $60 \mathrm{~min}$, and then the intracellular $\mathrm{pH}(\mathrm{pHi})$ level in the sperm was examined. Results are expressed as the means \pm s.E.M. $(n=6) .{ }^{*} P<0.05,{ }^{*} P<0.01$, as compared with the corresponding controls (0) (unpaired $t$-test).

dependent on the increase of intracellular $\mathrm{Ca}^{2+}$ (Visconti et al. 1995a, Zeng \& Tulsiani 2003). Surprisingly, our data showed that the antagonist of CCK1 or CCK2 receptor, as well as CCK8, still accelerated the capacitation-associated tyrosine phosphorylation when extracellular and intracellular $\mathrm{Ca}^{2+}$ in the sperm were abolished. Therefore, it is reasonable to conclude that the activation of sAC/CAMP/PKA-mediated phosphotyrosine pathway in sperm by CCK8 and its receptor antagonists were not coupled to the extracellular and intracellular $\mathrm{Ca}^{2+}$ mobilization.
Emerging evidence indicated that CCK and its receptors could also be involved in regulating the transport of $\mathrm{HCO}_{3}^{-}$(Sjoblom et al. 2013). Some evidence indicated that CCK was able to stimulate $\mathrm{HCO}_{3}^{-}$ secretion in a dose-dependent fashion, and this stimulatory effect of CCK was blocked completely by the CCK receptor antagonists (Yamazaki et al. 1996, Szalmay et al. 2001, Sjoblom et al. 2013). Here, we showed for the first time that CCK and its receptors could affect $\mathrm{HCO}_{3}^{-}$uptake in sperm, namely CCK and its receptor antagonists could accelerate the influx of $\mathrm{HCO}_{3}^{-}$in medium into sperm. $\mathrm{HCO}_{3}^{-}$is another key factor for sperm protein tyrosine phosphorylation. Mammalian sperm are enriched in the atypical sAC, which is not regulated by $\mathrm{G}$ proteins but rather by $\mathrm{HCO}_{3}^{-}$(Buck et al. 1999, Chen et al. 2000). sAC activation resulted in the stimulation of PKA and the enhancement of the tyrosine phosphorylation. Although it is well established that $\mathrm{HCO}_{3}^{-}$is essential for sperm capacitation, including tyrosine phosphorylation, there is no consensus as to how intracellular levels of this anion were regulated

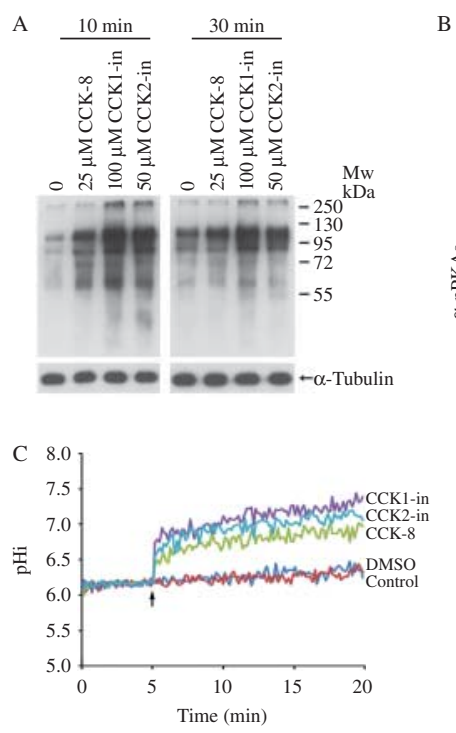

Figure 9 CCK8 and CCK receptor antagonists can activate SAC/CAMP/ PKA pathway by increasing intracellular $\mathrm{pH}$ via the influx of $\mathrm{HCO}_{3}^{-}$ in human sperm. (A) Sperm were treated with CCK8 $(25 \mu \mathrm{M})$, CCK receptor antagonists CR 1409 (CCK1-in, $100 \mu \mathrm{M})$ and PD135158 (CCK2-in, $50 \mu \mathrm{M}$ ) for 10 and $30 \mathrm{~min}$ in BWW medium. Protein tyrosine phosphorylation was then assessed by western blot analysis. $\alpha$-Tubulin was used as the loading control. The western blot is a representative of three independent experiments. (B) Sperm were treated with CCK8 $(25 \mu \mathrm{M})$, CCK receptor antagonists CR 1409 (CCK1-in, $100 \mu \mathrm{M})$ and PD135158 (CCK2-in, $50 \mu \mathrm{M}$ ) for 10 and 30 min in BWW medium. PKA substrate phosphorylation ( $\alpha$-pPKAs) was then assessed by western blot analysis. $\alpha$-Tubulin was used as the loading control. The western blot is a representative of three independent experiments. (C) Effects of CCK8 $(25 \mu \mathrm{M})$, CCK receptor antagonists CR $1409(\mathrm{CCK} 1$-in, $100 \mu \mathrm{M})$ and PD135158 (CCK2-in, $50 \mu \mathrm{M})$ on human sperm intracellular $\mathrm{pH}(\mathrm{pHi})$. The arrow indicates the time points at which the antagonists were added. A representative of three independent experiments is presented. 
(Florman et al. 2007). There is good evidence that the cystic fibrosis transmembrane conductance regulator (CFTR), initially described as a $\mathrm{Cl}^{-}$channel, may be involved in the transport of sperm $\mathrm{HCO}_{3}^{-}$(Xu et al. 2007). However, CFTR inhibitors were found to be unable to block the bicarbonate-dependent increase in tyrosine phosphorylation (Hernandez-Gonzalez et al. 2007). Some evidence has also suggested the involvement of the $\mathrm{Na}^{+} / \mathrm{HCO}_{3}^{-}$co-transporter and the anion transporter SLC26A3/A6 in the importation of $\mathrm{HCO}_{3}^{-}$ into sperm (Parkkila et al. 1993, Demarco et al. 2003). Our present study demonstrated the involvement of CCK and its receptor in regulation of sperm capacitationassociated tyrosine phosphorylation via the transport of $\mathrm{HCO}_{3}^{-}$in sperm; however, the detailed transport mechanism underlying the CCK receptor-regulated $\mathrm{HCO}_{3}$ - uptake in sperm remains to be investigated.

An interesting finding from our present study was that CCK8 had the same action on sperm as the antagonists of CCK receptors. CCK dose-response studies on pancreatic acini typically revealed a biphasic dose-response relationship, namely stimulation at low CCK concentrations and inhibition at supramaximal concentrations (Wank 1995). In our present work, the CCK1 or CCK2 receptor antibody could accelerate the sperm protein tyrosine phosphorylation and elevate the level of intracellular $\mathrm{HCO}_{3}^{-}$in sperm. The high and low dose of inhibitors also showed similar response. This suggests that CCK8 exerts the function by inhibiting its receptors in mature sperm. The endogenous CCK8 has been shown to be a substrate of TPPII, and TPPII is responsible for the major inactivation pathway of endogenous CCK8 (Rose et al. 1996). Our previous data demonstrated that TPPII protein was located in the region of mature sperm acrosome. TPPII antagonists could accelerate sperm capacitation-associated protein tyrosine phosphorylation. Furthermore, this effect of TPPII antagonists on tyrosine phosphorylation was also dependent on the presence of $\mathrm{HCO}_{3}^{-}$in the medium (Zhou et al. 2013). This was in agreement with that CCK8 effect on sperm depends on $\mathrm{HCO}_{3}^{-}$. This also implies the possibility that TPPII functions in association with CCK8 inactivation in sperm. However, further investigation is required to verify whether TPPII actually degrades CCK8 in sperm.

In conclusion, the present study has demonstrated for the first time the involvement of CCK and its receptors in the regulation of intracellular $\mathrm{HCO}_{3}^{-}$levels, thereby eliciting the sAC/cAMP/PKA-mediated capacitationassociated protein tyrosine phosphorylation pathway. The present findings have revealed an intrinsic mechanism involving sperm CCK and its receptors in regulating sperm capacitation and thus fertilization.

\section{Supplementary data}

This is linked to the online version of the paper at http://dx.doi. org/10.1530/REP-15-0138.

\section{Declaration of interest}

The authors declare that there is no conflict of interest that could be perceived as prejudicing the impartiality of the research reported.

\section{Funding}

This work was supported by grants from the National Key Basic Research Program (973 Program) (2014CB943103), National Natural Science Foundation of China (grant number 31471104 and 31171115).

\section{References}

Austin CR 1952 The capacitation of the mammalian sperm. Nature $\mathbf{1 7 0}$ 326-326. (doi:10.1038/170326a0)

Baker MA, Hetherington L, Ecroyd H, Roman SD \& Aitken RJ 2004 Analysis of the mechanism by which calcium negatively regulates the tyrosine phosphorylation cascade associated with sperm capacitation. Journal of Cell Science 117 211-222. (doi:10.1242/jcs.00842)

Battistone MA, Da Ros VG, Salicioni AM, Navarrete FA, Krapf D, Visconti PE \& Cuasnicu PS 2013 Functional human sperm capacitation requires both bicarbonate-dependent PKA activation and downregulation of Ser/Thr phosphatases by Src family kinases. Molecular Human Reproduction 19 570-580. (doi:10.1093/molehr/gat033)

Bourassa J, Laine J, Kruse ML, Gagnon MC, Calvo E \& Morisset J 1999 Ontogeny and species differences in the pancreatic expression and localization of the CCK(A) receptors. Biochemical and Biophysical Research Communications 260 820-828. (doi:10.1006/bbrc.1999.0988)

Brewis IA, Moore HD, Fraser LR, Holt WV, Baldi E, Luconi M, Gadella BM, Ford WC \& Harrison RA 2005 Molecular mechanisms during sperm capacitation. Human Fertility 8 253-261. (doi:10.1080/ 14647270500420178)

Buck J, Sinclair ML, Schapal L, Cann MJ \& Levin LR 1999 Cytosolic adenylyl cyclase defines a unique signaling molecule in mammals. PNAS 96 79-84. (doi:10.1073/pnas.96.1.79)

Chandra R \& Liddle RA 2007 Cholecystokinin. Current Opinion in Endocrinology, Diabetes, and Obesity 14 63-67. (doi:10.1097/MED. 0b013e3280122850)

Chang MC 1951 Fertilizing capacity of spermatozoa deposited into the fallopian tubes. Nature 168 697-698. (doi:10.1038/168697b0)

Chang MC 1955 Development of fertilizing capacity of rabbit spermatozoa in the uterus. Nature 175 1036-1037. (doi:10.1038/1751036a0)

Chen Y, Cann MJ, Litvin TN, lourgenko V, Sinclair ML, Levin LR \& Buck J 2000 Soluble adenylyl cyclase as an evolutionarily conserved bicarbonate sensor. Science 289 625-628. (doi:10.1126/science.289.5479.625)

Crawley JN \& Corwin RL 1994 Biological actions of cholecystokinin. Peptides 15 731-755. (doi:10.1016/0196-9781(94)90104-X)

Demarco IA, Espinosa F, Edwards J, Sosnik J, De La Vega-Beltran JL, Hockensmith JW, Kopf GS, Darszon A \& Visconti PE 2003 Involvement of a Na+/HCO-3 cotransporter in mouse sperm capacitation. Journal of Biological Chemistry 278 7001-7009. (doi:10.1074/jbc.M206284200)

Dunlop J 1998 CCK receptor antagonists. General Pharmacology 31 519-524. (doi:10.1016/S0306-3623(98)00078-0)

Dunlop J, Brammer N \& Ennis C 1996 Pharmacological characterization of a Chinese hamster ovary cell line transfected with the human CCK-B receptor gene. Neuropeptides 30 359-363. (doi:10.1016/S01434179(96)90025-6)

Dunlop J, Zhang Y \& Evans N 1997 Full and partial agonist activity of C-terminal cholecystokinin peptides at the cloned human CCK-A receptor expressed in Chinese hamster ovary cells. Peptides $\mathbf{1 8}$ 865-868. (doi:10.1016/S0196-9781(97)00012-0)

Dunlop J, Pass I \& Ennis C 1998 The cholecystokinin-B receptor antagonist L-740,093 produces an insurmountable antagonism of CCK-4 stimulated functional response in cells expressing the human CCK-B receptor. Neuropeptides 32 157-160. (doi:10.1016/S0143-4179(98)90031-2) 
Florman HM, Jungnickel MK \& Sutton KA 2007 What can we learn about fertilization from cystic fibrosis? PNAS 104 11123-11124. (doi:10.1073/ pnas.0703626104)

Fraire-Zamora JJ \& Gonzalez-Martinez MT 2004 Effect of intracellular pH on depolarization-evoked calcium influx in human sperm. American Journal of Physiology. Cell Physiology 287 C1688-C1696. (doi:10.1152/ ajpcell.00141.2004)

Hernandez-Gonzalez EO, Trevino CL, Castellano LE, de la Vega-Beltran JL, Ocampo AY, Wertheimer E, Visconti PE \& Darszon A 2007 Involvement of cystic fibrosis transmembrane conductance regulator in mouse sperm capacitation. Journal of Biological Chemistry 282 24397-24406. (doi:10.1074/jbc.M701603200)

Honda T, Wada E, Battey JF \& Wank SA 1993 Differential gene expression of $\mathrm{CCK}(\mathrm{A})$ and $\mathrm{CCK}(\mathrm{B})$ receptors in the rat brain. Molecular and Cellular Neurosciences 4 143-154. (doi:10.1006/mcne.1993.1018)

Hughes J, Boden P, Costall B, Domeney A, Kelly E, Horwell DC, Hunter JC, Pinnock RD \& Woodruff GN 1990 Development of a class of selective cholecystokinin type $\mathrm{B}$ receptor antagonists having potent anxiolytic activity. PNAS 87 6728-6732. (doi:10.1073/pnas.87.17.6728)

Krapf D, Arcelay E, Wertheimer EV, Sanjay A, Pilder SH, Salicioni AM \& Visconti PE 2010 Inhibition of Ser/Thr phosphatases induces capacitationassociated signaling in the presence of Src kinase inhibitors. Journal of Biological Chemistry 285 7977-7985. (doi:10.1074/jbc.M109.085845)

Kulaksiz H, Arnold R, Goke B, Maronde E, Meyer M, Fahrenholz F, Forssmann WG \& Eissele R 2000 Expression and cell-specific localization of the cholecystokinin B/gastrin receptor in the human stomach. Cell and Tissue Research 299 289-298. (doi:10.1007/ s004410050027)

Lee YM, Beinborn M, McBride EW, Lu M, Kolakowski LF Jr \& Kopin AS 1993 The human brain cholecystokinin-B/gastrin receptor. Cloning and characterization. Journal of Biological Chemistry 268 8164-8169.

Matozaki T, Sakamoto C, Nagao M, Nishizaki H \& Baba S 1988 G protein in stimulation of PI hydrolysis by CCK in isolated rat pancreatic acinar cells. American Journal of Physiology 255 E652-E659.

Matozaki T, Goke B, Tsunoda Y, Rodriguez M, Martinez J \& Williams JA 1990 Two functionally distinct cholecystokinin receptors show different modes of action on $\mathrm{Ca}^{2+}$ mobilization and phospholipid hydrolysis in isolated rat pancreatic acini. Studies using a new cholecystokinin analog, JMV-180. Journal of Biological Chemistry 265 6247-6254.

Matsusue K, Takiguchi S, Takata Y, Funakoshi A, Miyasaka K \& Kono A 1999 Expression of cholecystokinin type $\mathrm{A}$ receptor gene correlates with DNA demethylation during postnatal development of rat pancreas. Biochemical and Biophysical Research Communications 264 29-32. (doi:10.1006/bbrc.1999.1459)

Miyasaka K, Kanai S, Ohta M, Kawanami T, Kono A \& Funakoshi A 1994 Lack of satiety effect of cholecystokinin (CCK) in a new rat model not expressing the CCK-A receptor gene. Neuroscience Letters 180 143-146. (doi:10.1016/0304-3940(94)90507-X)

Miyasaka K, Kobayashi S, Ohta M, Kanai S, Yoshida Y, Nagata A, Matsui T, Noda T, Takiguchi S, Takata Y et al. 2002 Anxiety-related behaviors in cholecystokinin- $A, B$, and $A B$ receptor gene knockout mice in the plus-maze. Neuroscience Letters 335 115-118. (doi:10.1016/S03043940(02)01176-X)

Moriarty TM, Gillo B, Sealfon S \& Landau EM 1988 Activation of ionic currents in Xenopus oocytes by corticotropin-releasing peptides. Brain Research 464 201-205. (doi:10.1016/0169-328X(88)90026-5)

Muller W, Heinemann U \& Berlin K 1997 Cholecystokinin activates CCKB-receptor-mediated Ca-signaling in hippocampal astrocytes. Journal of Neurophysiology 78 1997-2001.

Mutt V 1994 Historical perspectives on cholecystokinin research. Annals of the New York Academy of Sciences 713 1-10. (doi:10.1111/j.17496632.1994.tb44046.x)

Naz RK \& Rajesh PB 2004 Role of tyrosine phosphorylation in sperm capacitation/acrosome reaction. Reproductive Biology and Endocrinology 2 75. (doi:10.1186/1477-7827-2-75)

Noble F, Wank SA, Crawley JN, Bradwejn J, Seroogy KB, Hamon M \& Roques BP 1999 International Union of Pharmacology. XXI. Structure, distribution, and functions of cholecystokinin receptors. Pharmacological Reviews 51 745-781.

Parkkila S, Rajaniemi H \& Kellokumpu S 1993 Polarized expression of a band 3-related protein in mammalian sperm cells. Biology of Reproduction 49 326-331. (doi:10.1095/biolreprod49.2.326)
Pelto-Huikko M, Persson H, Schalling M, Rehfeld JF \& Hokfelt T 1989 Immunocytochemical demonstration of cholecystokinin-like immunoreactivity in spermatozoa in monkey testis and epididymis. Acta Physiologica Scandinavica 137 465-466. (doi:10.1111/j.1748-1716.1989.tb08781.x)

Persson H, Ericsson A, Schalling M, Rehfeld JF \& Hokfelt T 1988 Detection of cholecystokinin in spermatogenic cells. Acta Physiologica Scandinavica 134 565-566. (doi:10.1111/j.1365-201X.1988.tb10638.x)

Persson H, Rehfeld JF, Ericsson A, Schalling M, Pelto-Huikko M \& Hokfelt T 1989 Transient expression of the cholecystokinin gene in male germ cells and accumulation of the peptide in the acrosomal granule: possible role of cholecystokinin in fertilization. PNAS 86 6166-6170. (doi:10.1073/ pnas.86.16.6166)

Roberts KP, Wamstad JA, Ensrud KM \& Hamilton DW 2003 Inhibition of capacitation-associated tyrosine phosphorylation signaling in rat sperm by epididymal protein Crisp-1. Biology of Reproduction 69 572-581. (doi:10.1095/biolreprod.102.013771)

Rose C, Vargas F, Facchinetti P, Bourgeat P, Bambal RB, Bishop PB, Chan SM, Moore AN, Ganellin CR \& Schwartz JC 1996 Characterization and inhibition of a cholecystokinin-inactivating serine peptidase. Nature 380 403-409. (doi:10.1038/380403a0)

Schackmann RW \& Chock PB 1986 Alteration of intracellular $\left[\mathrm{Ca}^{2+}\right]$ in sea urchin sperm by the egg peptide speract. Evidence that increased intracellular $\mathrm{Ca}^{2+}$ is coupled to $\mathrm{Na}^{+}$entry and increased intracellular $\mathrm{pH}$. Journal of Biological Chemistry 261 8719-8728.

Shimazoe T, Morita M, Ogiwara S, Kojiya T, Goto J, Kamakura M, Moriya T, Shinohara K, Takiguchi S, Kono A et al. 2008 Cholecystokinin-A receptors regulate photic input pathways to the circadian clock. FASEB Journal 22 1479-1490. (doi:10.1096/fj.07-9372com)

Simasko SM, Wiens J, Karpiel A, Covasa M \& Ritter RC 2002 Cholecystokinin increases cytosolic calcium in a subpopulation of cultured vagal afferent neurons. American Journal of Physiology. Regulatory, Integrative and Comparative Physiology 283 R1303-R1313. (doi:10.1152/ajpregu.00050.2002)

Sjoblom M, Lindqvist R, Bengtsson MW, Jedstedt G \& Flemstrom G 2013 Cholecystokinin but not ghrelin stimulates mucosal bicarbonate secretion in rat duodenum: independence of feeding status and cholinergic stimuli. Regulatory Peptides 183 46-53. (doi:10.1016/j.regpep.2013.03.008)

Svoboda M, Lambert M, Furnelle J \& Christophe J 1982 Specific photoaffinity crosslinking of [125I]cholecystokinin to pancreatic plasma membranes. Evidence for a disulfide-linked Mr 76000 peptide in cholecystokinin receptors. Regulatory Peptides 4 163-172. (doi:10. 1016/0167-0115(82)90084-2)

Szalmay G, Varga G, Kajiyama F, Yang XS, Lang TF, Case RM \& Steward MC 2001 Bicarbonate and fluid secretion evoked by cholecystokinin, bombesin and acetylcholine in isolated guinea-pig pancreatic ducts. Journal of Physiology 535 795-807. (doi:10.1111/j.1469-7793.2001.00795.x)

Vanhoutte PM, Humphrey PP \& Spedding M 1996 X. International Union of Pharmacology recommendations for nomenclature of new receptor subtypes. Pharmacological Reviews 48 1-2.

Visconti PE \& Kopf GS 1998 Regulation of protein phosphorylation during sperm capacitation. Biology of Reproduction 59 1-6. (doi:10.1095/ biolreprod59.1.1)

Visconti PE, Bailey JL, Moore GD, Pan D, Olds-Clarke P \& Kopf GS 1995a Capacitation of mouse spermatozoa. I. Correlation between the capacitation state and protein tyrosine phosphorylation. Development 121 1129-1137.

Visconti PE, Moore GD, Bailey JL, Leclerc P, Connors SA, Pan D, OldsClarke P \& Kopf GS 1995b Capacitation of mouse spermatozoa. II. Protein tyrosine phosphorylation and capacitation are regulated by a cAMP-dependent pathway. Development 121 1139-1150.

Visconti PE, Galantino-Homer H, Moore GD, Bailey JL, Ning X, Fornes M \& Kopf GS 1998 The molecular basis of sperm capacitation. Journal of Andrology 19 242-248. (doi:10.1002/j.1939-4640.1998.tb01994.x)

Visconti PE, Westbrook VA, Chertihin O, Demarco I, Sleight S \& Diekman AB 2002 Novel signaling pathways involved in sperm acquisition of fertilizing capacity. Journal of Reproductive Immunology 53 133-150. (doi:10.1016/S0165-0378(01)00103-6)

Wank SA 1995 Cholecystokinin receptors. American Journal of Physiology 269 G628-G646.

Wank SA, Harkins R, Jensen RT, Shapira H, de Weerth A \& Slattery T 1992 Purification, molecular cloning, and functional expression of the cholecystokinin receptor from rat pancreas. PNAS 89 3125-3129. (doi:10.1073/pnas.89.7.3125) 
Xu WM, Shi QX, Chen WY, Zhou CX, Ni Y, Rowlands DK, Yi Liu G, Zhu H, Ma ZG, Wang XF et al. 2007 Cystic fibrosis transmembrane conductance regulator is vital to sperm fertilizing capacity and male fertility. PNAS 104 9816-9821. (doi:10.1073/pnas.0609253104)

Yamazaki Y, Akahane M, Kobayashi M, Takeda H \& Ajisawa Y 1996 Effects of KSG-504, a new cholecystokinin-A-receptor antagonist, on pancreatic exocrine and endocrine secretions in rats. Japanese Journal of Pharmacology 70 183-190. (doi:10.1254/jjp.70.183)

Yang YM, Chung JM \& Rhim H 2007 Cholecystokinin-8S-induced intracellular calcium signaling in acutely isolated periaqueductal gray neurons of the rat. Biological \& Pharmaceutical Bulletin 30 297-302. (doi:10.1248/bpb.30.297)

Zeng HT \& Tulsiani DR 2003 Calmodulin antagonists differentially affect capacitation-associated protein tyrosine phosphorylation of mouse sperm components. Journal of Cell Science 116 1981-1989. (doi:10. $1242 /$ jcs.00396)
Zhou Y, Zheng M, Shi Q, Zhang L, Zhen W, Chen W \& Zhang Y 2008 An epididymis-specific secretory protein HongrES1 critically regulates sperm capacitation and male fertility. PLOS ONE 3 e4106. (doi:10. 1371/journal.pone.0004106)

Zhou Y, Ru Y, Wang C, Wang S, Zhou Z \& Zhang Y 2013 Tripeptidyl peptidase II regulates sperm function by modulating intracellular $\mathrm{Ca}(2+)$ stores via the ryanodine receptor. PLOS ONE 8 e66634. (doi:10.1371/ journal.pone.0066634)

Received 25 March 2015

First decision 10 April 2015

Revised manuscript received 10 July 2015

Accepted 14 July 2015 